\title{
НЕКОТОРЫЕ АСПЕКТЫ ИСПОЛЬЗОВАНИЯ БЕСПИЛОТНЫХ ЛЕТАТЕЛЬНЫХ АППАРАТОВ В КОНТЕКСТЕ РЕГУЛИРУЮЩЕЙ ДОКУМЕНТАЦИИ
}

Сайтов Кадамбай Гелдибаевич, магистрант факультета Авиакосмических технологий, Абдужабаров Нуриддин Анварович, научный руководитель, к.т.н., декан факультета Авиакосмических технологий,

Ташкентский государственный технический университет имени Ислама Каримова

DOI: https://doi.org/10.31435/rsglobal_ejits/31072019/6581

\section{ARTICLE INFO}

Received 17 May 2019

Accepted 14 July 2019

Published 31 July 2019

\section{KEYWORDS}

unmanned aerial vehicle, operator, European Union, regulation, registration, operation, training, educate, aviation.

\begin{abstract}
In this article describes some of the features of the legal and regulatory issues of importation, registration and operation of UAVs by the state aviation authorities. In particular, we present examples of regulation in the European Union, USA, Russia, Kazakhstan and Uzbekistan. Also gives some recommendations and conclusions on the improvement of the regulatory and technical documentation, as well as streamlining the process of preparation and training UAV operators.
\end{abstract}

Citation: Saytov K. G., Abdujabarov N. A. (2019) Some Aspects of the Use of Unmanned Aircrafts in the Context of Regulatory Documentation. European Journal of Intelligent Transportation Systems. 1(2). doi: 10.31435/rsglobal_ejits/31072019/6581.

Copyright: (C) 2019 Saytov K. G., Abdujabarov N. A. This is an open-access article distributed under the terms of the Creative Commons Attribution License (CC BY). The use, distribution or reproduction in other forums is permitted, provided the original author(s) or licensor are credited and that the original publication in this journal is cited, in accordance with accepted academic practice. No use, distribution or reproduction is permitted which does not comply with these terms.

К сегодняшнему дню беспилотные летательные аппараты (БПЛА) получают всё большее распространение во всем мире в различных сферах экономики и жизнедеятельности. Наряду с экономической выгодой, экономией времени, материальных ресурсов и человекочасов, использование БПЛА может причинить неудобства в сфере управления воздушным движением или же сохранения неприкосновенности стратегических объектов или защиты частной собственности (или жизни).

В целях регулирования вопросов, связанных с ввозом БПЛА, оформления разрешительной или иной документации, их эксплуатации во многих странах приняты нормативно-правовые акты, которые регулируют сферу использования данного вида летательных аппаратов.

В Европейском Союзе организацией EASA (European Aviation Safety Agency) приняты регулирующие документы "Notice of Proposed Amendment 2017-05 (А)" и "Notice of Proposed Amendment 2017-05 (В)" которыми утверждены “"Introduction of a regulatory framework for the operation of drones" (“Внедрение нормативной базы для эксплуатации беспилотников”) [1].

Согласно данных документов для регистрации БПЛА в Европейском Союзе предъявляются следующие требования (см. таблица 1)

В процессе разработки требований по регистрации и эксплуатации БПЛА странами членами ЕС были внесены различные предложения, которые были обобщены в приведены в виде следующей таблицы (таблица 2). 
Таблица 1. Основные требования при регистрации БПЛА в Европейском Союзе

\begin{tabular}{|c|c|c|}
\hline Номер опции & Краткое название & Описание \\
\hline R0 & Ничего не требуется & $\begin{array}{c}\text { Регистрация определяется странами членами } \\
\text { ЕС }\end{array}$ \\
\hline R1 & Оператор & Только оператор проходит регистрацию \\
\hline R2 & Оператор и БПЛА (не игрушки) & $\begin{array}{c}\text { Оператор и ЛА должны пройти регистрацию } \\
\text { (помимо игрушек) }\end{array}$ \\
\hline R3 & $\begin{array}{c}\text { Оператор и БПЛА (не игрушки и } \\
\text { БПЛА класса 1) }\end{array}$ & $\begin{array}{c}\text { Оператор и ЛА должны пройти регистрацию } \\
\text { (помимо игрушек и БПЛА класса 1) }\end{array}$ \\
\hline R4 & Регистарция в EASA & $\begin{array}{c}\text { Система регистрации разработана на уровне } \\
\text { ЕС (ЕАSA). }\end{array}$ \\
\hline
\end{tabular}

Таблица 2. Компромиссные (обобщенные) требования по регистрации и эксплуатации БПЛА в Европейском Союзе

\begin{tabular}{|c|c|c|c|c|c|c|c|c|}
\hline 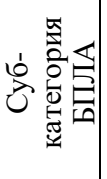 & 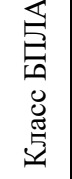 & $\ddot{\Perp}$ & $\begin{array}{l}\text { Расстояние от } \\
\text { людей }\end{array}$ & $\begin{array}{c}\text { Максимальная } \\
\text { высота } \\
\text { эксплуатации }\end{array}$ & $\begin{array}{c}\text { Компетенция } \\
\text { оператора }\end{array}$ & 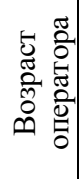 & $\begin{array}{c}\text { Основные } \\
\text { технические } \\
\text { требования }\end{array}$ & $\begin{array}{c}\text { Регистрация } \\
\text { БПЛА }\end{array}$ \\
\hline \multirow{3}{*}{ 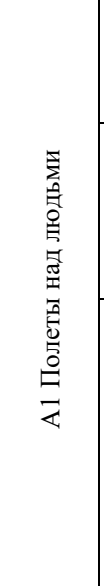 } & 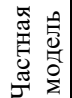 & \multirow[b]{2}{*}{$\begin{array}{l}\overrightarrow{0} \\
\stackrel{n}{v} \\
v\end{array}$} & \multirow{3}{*}{$\begin{array}{c}\text { Полеты над } \\
\text { незнакомыми } \\
\text { людьми (но н над } \\
\text { толпой, их } \\
\text { скоплением) }\end{array}$} & m & \multirow[b]{2}{*}{$\begin{array}{c}\text { Листовка } \\
\text { (плакат) }\end{array}$} & \multirow{2}{*}{ 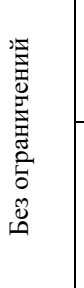 } & Нет данных & \multirow[b]{2}{*}{ Нет } \\
\hline & 8 & & & 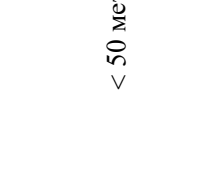 & & & $\begin{array}{c}\text { Игрушечная } \\
\text { инструкция, нет } \\
\text { острых краев, } \\
\text { информационная } \\
\text { листовка }\end{array}$ & \\
\hline & $\vec{U}$ & 宮 & & $\begin{array}{c}<120 \text { м или до } \\
50 \text { м над более } \\
\text { высоким } \\
\text { препятствием, } \\
\text { по требованию } \\
\text { владельца } \\
\text { объекта }\end{array}$ & $\begin{array}{c}\text { Листовка } \\
\text { (плакат) и } \\
\text { онлайн } \\
\text { обучения со } \\
\text { сдачей теста }\end{array}$ & 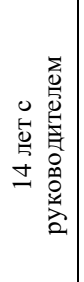 & $\begin{array}{c}\text { Кинетическая энергия, } \\
\text { нет острых краев, } \\
\text { выбираемый предел } \\
\text { высоты, } \\
\text { информационная } \\
\text { листовка }\end{array}$ & $\begin{array}{c}\text { ЕІ, если с } \\
\text { камерой> 5 } \\
\text { Мп или } \\
\text { аудио } \\
\text { сенсором, } \\
\text { ЕI и G, если } \\
\text { это требуется } \\
\text { зоной } \\
\text { эксплуатации }\end{array}$ \\
\hline 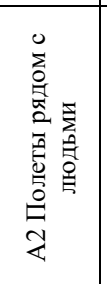 & U & 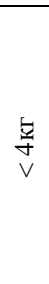 & $\begin{array}{c}\text { Запланированный } \\
\text { полет над людьми } \\
\text { на безопасной } \\
\text { дистанции ( } 20 \text { м } \\
\text { для вертолетного } \\
\text { типа и } 50 \text { м для } \\
\text { моделей с } \\
\text { неподвижным } \\
\text { крылом) }\end{array}$ & $\begin{array}{c}<120 \text { м или до } \\
50 \text { м над более } \\
\text { высоким } \\
\text { препятствием, } \\
\text { по требованию } \\
\text { владельца } \\
\text { объекта }\end{array}$ & $\begin{array}{c}\text { Листовка } \\
\text { (плакат) и } \\
\text { сертификат } \\
\text { компетентности } \\
\text { (теоретическая } \\
\text { квалификация) } \\
\text { и экзамен в } \\
\text { утвержденном } \\
\text { центре }\end{array}$ & 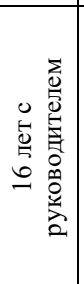 & $\begin{array}{c}\text { Механическая } \\
\text { прочность, управление } \\
\text { потерянными связями, } \\
\text { выбираемый предел } \\
\text { высоты, } \\
\text { информационная } \\
\text { листовка }\end{array}$ & Да \\
\hline \multirow{3}{*}{ 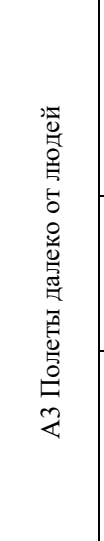 } & 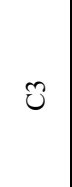 & \multirow{3}{*}{$\begin{array}{l}\stackrel{5}{n} \\
\stackrel{\sim}{v} \\
v\end{array}$} & $\begin{array}{c}\text { Полеты в зоне, } \\
\text { где разумно } \\
\text { ожидать } \\
\text { отсутствия } \\
\text { посторонних } \\
\text { людей }\end{array}$ & \multirow{3}{*}{$\begin{array}{c}<120 \text { м или до } \\
50 \text { м над более } \\
\text { высоким } \\
\text { препятствием, } \\
\text { по требованию } \\
\text { владельца } \\
\text { объекта }\end{array}$} & \multirow{3}{*}{$\begin{array}{c}\text { Листовка } \\
\text { (плакат) и } \\
\text { онлайн } \\
\text { обучения со } \\
\text { сдачей теста }\end{array}$} & \multirow{3}{*}{ 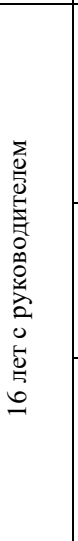 } & $\begin{array}{c}\text { Управление } \\
\text { потерянными связями, } \\
\text { выбираемый предел } \\
\text { высоты, } \\
\text { информационная } \\
\text { листовка }\end{array}$ & \multirow{3}{*}{$\begin{array}{c}\text { Если этого } \\
\text { требует зона } \\
\text { эксплуатации }\end{array}$} \\
\hline & オ & & $\begin{array}{c}\text { В дополнение к } \\
\text { вышесказанному, } \\
\text { соблюдайте } \\
\text { безопасное } \\
\text { расстояние от }\end{array}$ & & & & $\begin{array}{c}\text { Инструкция по } \\
\text { эксплуатации, } \\
\text { информационная } \\
\text { листовка }\end{array}$ & \\
\hline & 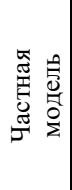 & & $\begin{array}{c}\text { границ } \\
\text { перегруженных } \\
\text { районов городов, } \\
\text { поселков или } \\
\text { населенных } \\
\text { пунктов или } \\
\text { аэродромов }\end{array}$ & & & & Нет данных & \\
\hline
\end{tabular}

Во второй части европейских регулирующих документов приведены требования по компетенции операторов БПЛА, в том числе ограничения по возрасту, необходимой 
компетенции и теоретическим знаниям в области управления воздушным движения, полетом летательных аппаратов и авиационной безопасности.

В Российской Федерации ввоз дронов весом до 250 граммов возможен без регистрации. Регистрации подлежают беспилотники весом от 250 граммов до 30 кг. Предполагается что регистрация будет осуществляется онлайн и бесплатно, а владельцам БПЛА по почте будут высланы специальные радиочастотные (RFID) метки, которые должны будут прикреплены на корпус дрона. При помощи данной метки дрон можно будет распознать на расстоянии до 300 метров. На данный момент ФГУП «ЗащитаИнфоТранс» не производит постановку на учет беспилотных летательных аппаратов. В РФ довольно-таки проблематично получить разрешение на полеты дронов весом свыше 250 граммов, есть своя процедура и ограничения по зонам полетов [2].

В Казахстане дроны весом до 1,5 кг можно ввозить и без какой-либо регистрации (учета). А эксплуатация беспилотников регулируется соответствующими НПА и порядком, с которым можно ознакомиться на сайте Комитета гражданской авиации Министерства индустрии и инфраструктурного развития Республики Казахстан. Также, как и в РФ, для полётов дронов весом свыше 1,5 кг необходимо получить разрешение на осуществление полетов [3].

В США согласно правилам FAA (Federal Aviation Administratoin, Федеральное управление гражданской авиации США) дроны весом до 250 граммов используются без регистарции. А модели весом от 250 граммов до 25 килограммов можно зарегистрировать онлайн (оплата 5 долларов за каждаый экземпляр, сроком до 3-х лет. Возраст лица производяшщег регистрацию должен быть не менее 13 лет. После регистрации владельцу выдается специальный стикер, который необходимо наклеить на корпус беспилотника [4].

В Узбекистане вопросы ввоза, регистрации и эксплуатации БПЛА регулируются рядом соответствующих нормативно-правовых актов. Наиболее важными из них являются «Воздушный кодекс», «Положение о порядке эксплуатации беспилотных летательных аппаратов в гражданской и государственной авиации Республики Узбекистан» и «Основные правила полетов авиации в воздушном пространстве Республики Узбекистан» [5].

Данными документами определены требования по ввозу, регистрации и эксплуатации БПЛА для юридических и физических лиц. В частности, в Положении о порядке эксплуатации беспилотных летательных аппаратов в гражданской и государственной авиации Республики Узбекистан дано следующее определение: «игрушечная модель воздушного судна используемый для удовлетворения личных потребностей граждан летательный аппарат весом не более 250 грамм, не подпадающий под код ТН ВЭД 880220000 0, без функции автономного управления полетом и навигации, не оборудованный фото - и видеоаппаратурой». Исходя из этого, все БПЛА, выходящие за рамки данного описания, должны проходить государственную регистрацию в уполномоченном органе. Кроме того, согласно пункту 7 данного положения, БПЛА гражданской авиации должны соответствовать следующим требованиям:

а) быть промышленного изготовления;

б) иметь паспорт завода-изготовителя или эквивалентный документ (сертификат качества, сертификат соответствия);

в) иметь максимальную взлетную массу не более 25 кг.

Вместе с этим, дано описание оператору беспилотного летательного аппарата гражданской авиации, согласно которого - это должностное лицо заявителя, непосредственно осуществляющее управление беспилотным летательным аппаратом. А также утверждены требования, предъявляемые к операторам:

а) иметь гражданство Республики Узбекистан;

б) возраст не моложе 18 лет;

в) по состоянию здоровья быть годным к выполнению должностных обязанностей;

г) иметь специальную подготовку по эксплуатации и управлению беспилотным летательным аппаратом, основанную на рекомендациях производителя (поставщика) беспилотных летательных аппаратов;

д) знать законодательство Республики Узбекистан по использованию воздушного пространства;

3) продемонстрировать уровень знаний и умений, позволяющий эксплуатировать беспилотный летательный аппарат. 
К настоящему времени систематической подготовки, обучения (тренинга) или повышения квалификации с последующей сертификацией операторов БПЛА не наблюдается.

В то же время, решением Правительства введены ограничения на ввоз, реализацию и использование БПЛА, за исключением случаев ввоза и использования беспилотных летательных аппаратов Государственным унитарным предприятием «Геоинновационный центр» при Государственном комитете Республики Узбекистан по земельным ресурсам, геодезии, картографии и государственному кадастру и предусмотренных отдельными решениями Кабинета Министров Республики Узбекистан [6].

Также БПЛА могут кратковременно ввозить творческие группы по ходатайству Государственного комитета Республики Узбекистан по развитию туризма, Министерства культуры Республики Узбекистан и Национального агентства «Узбеккино».

Для развития сферы применения БПЛА в различных отраслях экономики необходимо будет совместно с заинтересованными сторонами решить ряд организационных и технических вопросов:

1) пересмотра и гармонизации регулирующей документации и технических регламентов, возможной организации онлайн платформы для регистрации БПЛА а также ведение единой базы данных;

2) создание сертифицированного учебного центра для подготовки и тренинга операторов БПЛА (с последующей выдачей сертификатов), а также разработать учебнометодическую документацию, учебные и дидактические материалы и проведение практических занятий для слушателей курсов

3) дальнейшее изучение возможностей и сфер применения БПЛА в различных отраслях экономики, с расчётом прогнозных показателей и ожидаемой выгоды от их применения;

4) организации сервисной сети по техническому обслуживанию и ремонту эксплуатируемых БПЛА, в дальнейшем, возможной локализации производства БПЛА, их адаптации под климатические и другие особенности региона и сфер применения;

5) расширения международного сотрудничества с ведущими научными и образовательными центрами, развития местной научной школы в данном направлении.

Расширение сферы применения БПЛА в повседневной жизни, автоматизация с их помощью производственных и операционных процессов, а также замена ими классических инструментариев вопрос ближайшего времени, и для того чтобы не быть в «роли догоняющих» необходимо обратить пристальное внимание для решения вышеуказанных вопросов с привлечением компетентных специалистов и изучением международного опыта.

\section{ЛИТЕРАТУРА}

1. EASA "Notice of Proposed Amendment 2017-05 (A), (B) - Introduction of a regulatory framework for the operation of drones - Unmanned aircraft system operations in the open and specific category" (Нормативный документ Европейского агентства авиационной безопасности "Введение нормативной базы для эксплуатации беспилотных летательных аппаратов. Эксплуатация беспилотных авиационных систем в открытой и специальной категории") https://www.easa.europa.eu/document-library/notices-of-proposed-amendment/npa-2017-05;

2. https://profpv.ru/zakon-o-bespilotnikah-v-rf-nuzhno-li-reg/;

3. http://aviation.miid.gov.kz/ru/kategorii/poryadok-ispolzovaniya-bespilotnyh-letatelnyh-apparatov;

4. https://faadronezone.faa.gov/\#/;

5. Постановление Кабинета Министров Республики Узбекистан №287 «Об утверждении Положения о порядке эксплуатации беспилотных летательных аппаратов в гражданской и государственной авиации Республики Узбекистан» от 31.08.2016 года (http://lex.uz/docs/3024319);

6. Постановление Кабинета Министров Республики Узбекистан №322 «О мерах по предупреждению несанкционированного использования беспилотных летательных аппаратов в воздушном пространстве Республики Узбекистан» от 26.11.2014 года (http://lex.uz/docs/2503508);

7. Постановление Кабинета Министров Республики Узбекистан №349 «Об утверждении Основных правил полетов авиации в воздушном пространстве Республики Узбекистан» от 18.10.2016 года (http://lex.uz/docs/3045206);

8. Воздушный кодекс Республики Узбекистан; 